\author{
Piotr Idczak ${ }^{*}$ \\ Uniwersytet Ekonomiczny w Poznaniu \\ Karol Mrozik* \\ Uniwersytet Przyrodniczy w Poznaniu
}

\title{
EFEKTYWNOŚĆ EKONOMICZNA JAKO KATEGORIA WYKORZYSTYWANA W EWALUACJI EX ANTE ROZWIAZZAŃ KSZTAŁTUJĄCYCH RETENCJĘ ZLEWNI RZECZNEJ
}

\begin{abstract}
STRESZCZENIE
Analiza kosztów i korzyści sprowadza się do zestawienia potencjalnych korzyści wynikających z wdrożenia określonych działań i kosztów poniesionych na ich realizacje. W efekcie uzyskuje się klarowną informację na temat adekwatności przyjętych rozwiązań pod kątem ich skuteczności w osiąganiu przyszłych oczekiwań. W tym sensie efektywność ekonomiczna jest wykorzystywana w ewaluacji ex ante, ponieważ z wyprzedzeniem wskazuje, czy planowane działania są trafne z punktu widzenia potrzeb społecznych. Uwzględnia określony kontekst społeczno-gospodarczy i identyfikuje potencjalne trudności oraz proponuje rekomendacje, co zostało pokazane na przykładzie planowej budowy zbiornika małej retencji Tulce.
\end{abstract}

Słowa kluczowe: efektywność ekonomiczna, ewaluacja ex ante, analiza kosztów i korzyści, zbiornik małej retencji Tulce

\section{Wprowadzenie}

Efektywność ekonomiczna jest kategorią powszechnie wykorzystywaną w procesie decyzyjnym do weryfikacji skuteczności i ekonomiczności plano-

\footnotetext{
* Adres e-mail: piotr.idczak@ue.poznan.pl.

** Adres e-mail: kmrozik@up.poznan.pl.
} 
wanych bądź prowadzonych działań. Jej zastosowanie jest szczególnie istotne w przypadku projektów publicznych, od których oczekuje się, aby z jednej strony w pełni zaspakajały zbiorowe potrzeby społeczne, a z drugiej - były realizowane przy możliwe najniższym koszcie dla społeczeństwa. Dlatego w przypadku podejmowania przedsięwzięć publicznych konieczne jest zagwarantowanie racjonalnego uzasadnienia dla takich projektów. Po pierwsze, odnosi się to do weryfikacji ich zgodności z przyjętymi celami zapisanymi w planach bądź programach zawierających określoną politykę rozwoju w danym obszarze. Po drugie, oznacza to zapewnienie wydajnej i skutecznej alokacji ograniczonych zasobów finansowych umożliwiających osiągnięcie założonych celów. W tym kontekście ostatnio szeroko promuje się wykorzystywanie ewaluacji ex ante, która ma pomóc w lepszym planowaniu podejmowanych działań i służyć weryfikacji racjonalności planowania, umożliwia bowiem ocenę przedsięwzięcia jeszcze przed rozpoczęciem jego realizacji oraz wskazuje rekomendacje warunkujące szanse jego powodzenia.

Przeprowadzenie ewaluacji ex ante jest również uzasadnione w przypadku przedsięwzięć podejmowanych w celu przeciwdziałania niekorzystnym przyrodniczym zjawiskom ekstremalnym, jakimi są np. susze i powodzie. Zjawiska te są szczególnie widoczne na terenach o dużym udziale powierzchni nieprzepuszczalnych. Dotyczy to nie tylko terenów miejskich, ale coraz częściej również podlegających intensywnej suburbanizacji obszarów wiejskich zlokalizowanych w bezpośrednim sąsiedztwie dużych miast ${ }^{1}$. Skala zjawiska oraz zakres możliwych do zastosowania rozwiązań zaradczych wymagają zachowania szczególnej racjonalności w procesie decyzyjnym i planistycznym. Metody stosowane w ocenie efektywności ekonomicznej mogą zostać z powodzeniem wykorzystane w tym przypadku jako element ewaluacji ex ante. Dlatego też celem niniejszego artykułu jest przeprowadzenie oceny efektywności ekonomicznej jako elementu ewaluacji ex ante budowy planowanego zbiornika małej retencji (ZMR) Tulce w zlewni rzeki Męciny w gminie Kleszczewo w Poznańskim Obszarze Metropolitalnym służącego poprawie retencji zlewni oraz ukazanie użyteczności takiego podejścia w procesie planowania rozwiązań kształtujących retencję zlewni rzecznej.

${ }^{1}$ K. Mrozik, C. Przybyła, Problemy zarzadzania zasobami wodnymi w procesie suburbanizacji na przykładzie Poznańskiego Obszaru Metropolitalnego, „Finanse Komunalne” 2012, nr 12, s. 37-48. 


\section{Ewaluacja ex ante projektów środowiskowych}

Podstawowym zadaniem ewaluacji jest sprawdzenie, na ile przedmiot badania spełnia postawione przed nim założenia, tj. czy możliwe będzie osiągnięcie celów warunkujących powodzenie określonego przedsięwzięcia. Polega zatem na przeprowadzeniu badania społeczno-ekonomicznego mającego na celu ocenę jakości i efektów planowanych, prowadzonych bądź zrealizowanych działań. Oznacza to, że ewaluacja dostarcza wiedzy na temat jakości i wartości analizowanego przedsięwzięcia. Uzyskane w ten sposób wnioski i rekomendacje umożliwiają z kolei, jeśli jest to konieczne, zainicjowanie odpowiedniej reakcji skutkującej zaproponowaniem zmian. Decydent uzyskuje w ten sposób nie tylko wiedzę na temat tego, jakie działania są nieskuteczne, ale również jakie należy podjąć kroki zaradcze. Ewaluacja jest badaniem systematycznym, prowadzonym przy użyciu różnych metod stosowanych w celu zbierania danych, ich analizy i oceny oraz informowania o wynikach. Jej celem jest oszacowanie na podstawie jasno zdefiniowanych kryteriów jakości i wartości procesu realizacji przedsięwzięcia oraz efektów wdrażania interwencji publicznych ${ }^{2}$.

W literaturze podkreśla się, iż cechą ewaluacji bazującej na ciągłym procesie badawczym jest to, że dostarcza kryteriów, metod i technik, które z powodzeniem mogą być zastosowane do oceny racjonalności działań publicznych (wykorzystania środków publicznych) ukierunkowanych na poprawę dobrobytu społecznego. Co więcej, wnioski z procesu ewaluacji pozwalają na lepsze zrozumienie procesów społeczno-gospodarczych oraz identyfikowanie metod pobudzania rozwoju, a zatem wzmacniają procesy uczenia się 3 .

Szczególnym rodzajem ewaluacji jest ewaluacja ex ante dokonywana przed rozpoczęciem planowanego do realizacji przedsięwzięcia. Jej celem jest określenie trafności zidentyfikowanych potrzeb, jak również oszacowanie potencjalnego wpływu danego przedsięwzięcia (o charakterze interwencji publicznej) na sytuację społeczno-gospodarczą. Dokonując ewaluacji ex ante, należy oszacować szanse realizacji zakładanych celów, ale także skonfrontować możliwości ich osiągnięcia z doborem określonych instrumentów, biorąc przy tym pod uwagę dostępne zasoby (rysunek 1). Prawidłowe przeprowadzenie tego typu ewaluacji narzuca konieczność uwzględ-

${ }^{2}$ Ewaluacja. Poradnik dla pracowników administracji publicznej, Ministerstwo Rozwoju Regionalnego, Warszawa 2012, s. 11-12.

${ }^{3}$ K. Olejniczak, Mechanizmy wykorzystania ewaluacji. Studium ewaluacji średniookresowych Interreg III, Scholar, Warszawa 2008, s. 16-17. 
nienia szerszego kontekstu społeczno-gospodarczego ${ }^{4}$. Istota ewaluacji ex ante sprowadza się do odpowiedzi na pytania określające najważniejsze zagadnienia, które jednocześnie stanowią kryteria oceny i pozwalają na wyciągnięcie wniosków ${ }^{5}$.

Rysunek 1. Efektywność elementem ewaluacji ex ante

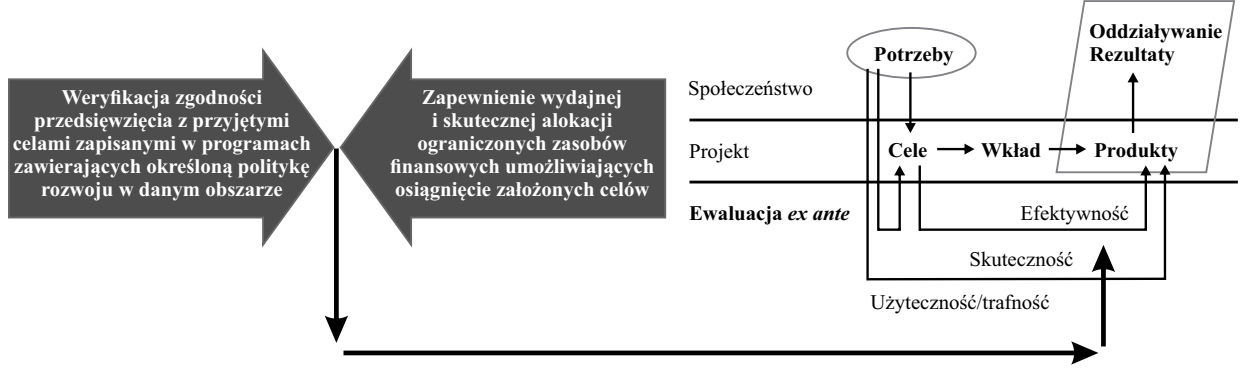

Źródło: opracowanie własne na podstawie Metodologiczny dokument roboczy. Projekt dokumentu roboczego dot. ewaluacji ex ante, Komisja Europejska, Bruksela 2005, s. 7.

Przedmiot niniejszej analizy skupia się wokół kwestii efektywności, czyli koncentruje się na zapewnieniu optymalizacji alokacji zasobów (pozostałe zagadnienia nie są badane). Ocena możliwości realizacji projektu środowiskowego przed rozpoczęciem jego wdrażania powinna być dokonana równie kompleksowo jak w przypadku przedsięwzięć nastawionych na zysk. Oznacza to, że do rachunku korzyści i kosztów finansowych należy włączyć także efekty zewnętrzne oddziaływania planowanej inwestycji.

\section{Efektywność ekonomiczna w procesie decyzyjnym}

Efektywność ekonomiczna jest miarą korzyści netto dla społeczeństwa wynikających z realizacji określonego przedsięwzięcia ${ }^{6}$. Ma na celu określenie, w jakim stop-

${ }^{4}$ Ewaluacja polityki..., s. 28-30.

5 Do tych zagadnień należą: trafność (relevance), skuteczność (effectiveness), efektywność (efficiency), użyteczność (utility), trwałość (sustainability). Więcej zob. Evalsed. The Resource for the Evaluation of Socio-Economic Development, European Commission 2013, s. 33-36.

${ }^{6}$ Zgodnie z teorią ekonomii dobrobytu korzyści netto dla społeczeństwa stanowią nadwyżkę korzyści nad kosztami społecznymi. K. Malik, Ewaluacja polityki rozwoju regionu. Metody, konteksty i wymiary rozwoju zrównoważonego, Studia KPZK PAN, z. 135, Warszawa 2011, s. 93. 
niu wkład przedsięwzięcia przyczyni się do tworzenia dobrobytu społecznego. Analiza ta jest wykonywana z punktu widzenia całego społeczeństwa, a więc wielu uczestników/odbiorców przedsięwzięcia, a nie tylko pojedynczego inwestora, jak ma to miejsce np. w przypadku analizy finansowej ${ }^{7}$. Analiza ekonomiczna uwzględnia nie tylko wielkości związane z przepływami pieniężnymi, ale również obejmuje te dziedziny, które niekoniecznie muszą być przedmiotem transakcji rynkowych. Uwzględnia koszty i korzyści społeczne, które nie stanowią przepływów pieniężnych. Najczęściej są to dziedziny charakterystyczne dla usług publicznych ukierunkowanych na zaspokajanie podstawowych potrzeb społecznych ${ }^{8}$. Ocenie efektywności ekonomicznej mogą zostać poddane przedsięwzięcia publiczne, które prowadzą m.in. do wdrożenia nowych funkcji kulturalnych i rekreacyjno-turystycznych, poprawy estetyki i funkcji przestrzeni publicznych, implementacji nowych usług publicznych, a także do poprawy stanu środowiska naturalnego i w konsekwencji warunków życia mieszkańców.

Analizę oceny efektywności ekonomicznej projektów publicznych można przeprowadzić, wykorzystując analizę kosztów i korzyści (cost benefit analysis). Metoda ta zakłada oddzielne oszacowanie wartości monetarnej wszystkich korzyści i kosztów wynikających z realizacji określonego projektu. W kolejnym etapie wartości te są wykorzystywane do korygowania przepływów środków pieniężnych zawartych w analizie finansowej. Następnie obliczane są wskaźniki efektywności ekonomicznej, np. ekonomiczna wartość bieżąca netto (ENPV), ekonomiczna stopa zwrotu (ERR) oraz stosunek korzyści do kosztów (B/C), których interpretacja pozwala ocenić, czy projekt jest ekonomicznie efektywny ${ }^{9}$. Metoda ta pomimo swojej kompleksowości ma jednak wiele ograniczeń. Wśród nich wymienić należy m.in. ograniczenia techniczne dotyczące trudności z wyceną kosztów i korzyści, rozbieżność celów, które nie zawsze stawiają na pierwszym miejscu efektywność, czy brak dostępnych danych ${ }^{10}$.

${ }^{7}$ Przewodnik do analizy kosztów i korzyści projektów inwestycyjnych, Komisja Europejska, Bruksela 2008 , s. 50.

${ }^{8}$ Więcej na ten temat zob. A. Drobniak, Zastosowanie analizy kosztów i korzyści w ocenie projektów publicznych, Wydawnictwo Akademii Ekonomicznej w Katowicach, Katowice 2002, s. 120-122; F. Piontek, Metodyka oceny efektywności wydatkowania ekologicznych funduszy celowych, „Rocznik Ochrony Środowiska” 1999, t. I, s. 215-228; B. Kryk, Rachunek sozoekonomiczny działalności gospodarczej na przyktadzie energetyki zawodowej regionu szczecińskiego, Wydawnictwo Naukowe Uniwersytetu Szczecińskiego, Szczecin 2003.

${ }^{9}$ Więcej na ten temat zob. Przewodnik do analizy... oraz A. Becla, S. Czaja, A. Zielińska, Analiza kosztów - korzyści w wycenie środowiska przyrodniczego, Difin, Warszawa 2012.

${ }^{10}$ Więcej na ten temat zob. A. Drobniak, Zastosowanie analizy..., s. 120-122; F. Piontek, Metodyka oceny..., s. 215-228; K. Malik, Ewaluacja polityki..., s. 122. 


\section{Efektywność ekonomiczna ZMR Tulce}

Przykładem obszaru, gdzie nastąpiło nasilenie zjawisk niepożądanych (susze lub lokalne podtopienia i powodzie), jest Poznański Obszar Metropolitalny ${ }^{11}$. Pilną potrzebą jest podjęcie działań z zakresu racjonalizacji gospodarowania zasobami wodnymi i opóźniania odpływu wód powierzchniowych.

Przykładem inwestycji wychodzącej naprzeciw temu problemowi jest planowany do realizacji do $2021 \mathrm{r}$. zbiornik małej retencji Tulce (ZMR Tulce) ${ }^{12}$ (lub Mę$\operatorname{cina}^{13}$ ) położony w dolinie rzeki Męciny w gminie wiejskiej Kleszczewo w powiecie poznańskim (rysunek 2). Budowa zbiornika wodnego na cieku naturalnym, w dodatku na cieku głównym jednolitej części wód powierzchniowych (JCWP), wiąże się ze znacznymi zmianami hydromorfologicznymi (zmiana ekosystemu wód płynących w ekosystem wód stojących oraz przerwanie ciągłości morfologicznej cieku). W związku z tym tę inwestycję zgodnie z oceną dokonaną na potrzeby MasterPlanu zaliczono jako możliwie wpływającą na stan/potencjał JCWP, mogącą spowodować nieosiągnięcie dobrego stanu/potencjału lub pogorszenie stanu/potencjału jednolitej części wód Kopel do Głuszynki (kod RW600016185747).

Głównym celem budowy ZMR jest ochrona przed suszą i powodzią, a sama inwestycja spełnia przesłanki art. 4 ust. 7 Ramowej Dyrektywy Wodnej (RDW), co umożliwia zastosowanie odstępstw od art. 4 RDW. Przyczyny zmian lub modyfikacji stanu/potencjału JCWP stanowią bowiem nadrzędny interes społeczny, tj. ochronę przed powodzią (nagłymi wezbraniami z deszczy nawalnych) dla terenów wsi Komorniki. Retencjonowanie wód przyczyni się ponadto do poprawy warunków wodnych w okresach deficytowych.

$\mathrm{Z}$ uwagi na fakt, że planowana inwestycja ma charakter interwencji publicznej służącej poprawie szeroko rozumianego interesu społeczno-gospodarczego, zasadne jest przeprowadzenie ewaluacji ex ante przyjętego rozwiązania. Z racji ograniczeń w tym celu wykorzystano tzw. podejście do ewaluacji bazujące na teorii (theorybased), które koncentruje się na identyfikacji, weryfikacji i ocenie założeń dotyczą-

${ }^{11}$ Szerzej ten problem opisali K. Mrozik, C. Przybyła, Problemy zarzadzania...

12 ID projektu 2_71_O zgodnie z MasterPlanem dla obszaru dorzecza Odry, KZGW, Warszawa 2014.

${ }^{13}$ Zgodnie ze Studium uwarunkowań i kierunków zagospodarowania przestrzennego gminy Kleszczewo (uchwała Rady Gminy Kleszczewo nr XVIII/132/2012 z 25 kwietnia 2012 r.) zbiornik na rzece Męcinie w okolicach Tulec wymieniony został wśród zadań służących realizacji ponadlokalnych celów publicznych. 
cych mechanizmu interwencji oraz relacji między działaniami a efektami ${ }^{14}$. W tym przypadku, dokonując oceny efektywności ekonomicznej, należy odpowiedzieć na pytanie, czy alokowane nakłady pozwolą na osiągnięcie zakładanych celów, tj. zabezpieczenia przeciwpowodziowego mieszkańców i poprawy stosunków wodnych w okresach suszy, a także w konsekwencji doprowadzą do wygenerowania istotnych korzyści dla całej społeczności. Działanie to będzie możliwe dzięki zastosowaniu metod z zakresu analizy kosztów i korzyści.

Rysunek 2. Położenie planowanego ZMR Tulce na tle sieci hydrograficznej zlewni oraz użytkowania terenu w zlewni Męciny

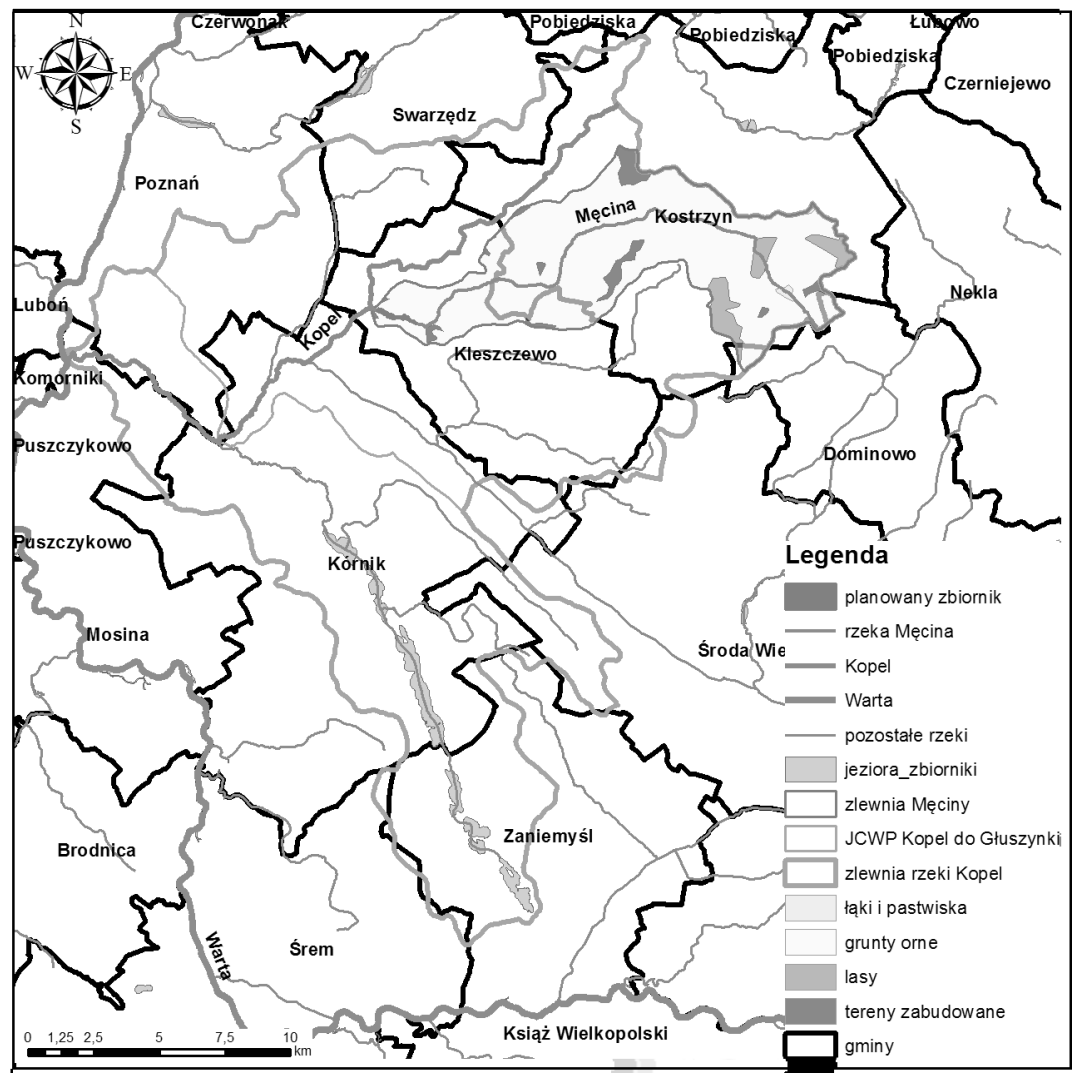

Źródło: opracowanie własne.

${ }^{14}$ K. Olejniczak, Mechanizmy wykorzystania ewaluacji..., s. 35. 
W badaniu oceny efektywności ekonomicznej budowy analizowanego zbiornika przyjęto następujące założenia ${ }^{15}$ :

a) uwzględniono wartość pieniądza w czasie (dyskonto);

b) w analizie zastosowano ceny stałe;

c) jako okres analizy (równy okresowi gospodarczego życia projektu) przyjęto 30 lat;

d) w analizie uwzględniono nakłady inwestycyjne ponoszone w okresie realizacji zbiornika oraz koszty eksploatacyjne występujące w całym okresie jego funkcjonowania;

e) przyjęto stopę dyskontową na poziomie $5,0 \%{ }^{16}$;

f) zidentyfikowano oraz oszacowano (wyceniono) potencjalne korzyści i koszty zewnętrzne wynikające $\mathrm{z}$ istnienia zbiornika;

g) przepływy finansowe skorygowano o efekty zewnętrzne oraz efekty fiskalne (podatek VAT w wysokości 23\% nakładów inwestycyjnych).

Wyniki przeprowadzonej analizy przedstawiono w tabeli 1.

Tabela 1. Ocena efektywności ekonomicznej budowy zbiornika Tulce

\begin{tabular}{|l|l|r|}
\hline Lp. & Nazwa & \multicolumn{1}{c|}{ zł } \\
\hline I. Nakłady inwestycyjne i koszty eksploatacyjne & 11206000,00 \\
\hline I.1 & Wartość nakładów inwestycyjnych* & 143820,00 \\
\hline I.1. & Wartość kosztów eksploatacyjnych (rocznie) & 327536,53 \\
\hline II. Identyfikacja i kwantyfikacja korzyści i kosztów zewnętrznych & 727,28 \\
\hline II.1 & Korzyści z tytułu nawadniania deszczownianego użytków rolnych (rocznie) $)^{* * *}$ & 11250000,00 \\
\hline II.1 & Korzyści z tytułu ochrony przeciwpowodziowej (rocznie) $)^{* * * *}$ & \\
\hline II.3 & $\begin{array}{l}\text { Wzrost wartości nieruchomości (łącznie w pierwszych dwóch latach po } \\
\text { oddaniu do użytkowania) }\end{array}$ & 214505,00 \\
\hline II. 4 & Koszty nawadniania użytków rolnych (rocznie) & \\
\hline III. Ws** & 540991,01 \\
\hline III.1 & ENPV & $8,95 \%$ \\
\hline III.1 & EIRR & 1,24 \\
\hline III.3 & B/C & \\
\hline
\end{tabular}

${ }^{15}$ Założenia przyjęto, bazując na zaleceniach zawartych w: Guide to Cost-benefit Analysis of Investment Projects. Economic Appraisal Tool for Cohesion Policy 2014-2020, European Commission, Luxembourg 2014.

${ }^{16}$ Zastosowano tutaj tzw. społeczną stopę dyskontową (social discount rate). Więcej na ten temat zob. tamże, s. 44. 
* Na podstawie MasterPlan dla obszaru dorzecza Odry, KZGW, Warszawa 2014.

** W kalkulacji uwzględniono średni jednostkowy koszt eksploatacji zbiornika retencyjnego, tj. $0,02 \mathrm{zł} / \mathrm{m}^{3}$, oraz jednostkowy wskaźnik strat spowodowanych zmniejszeniem zdolności wód do samooczyszczania, który wynosi $0,92 \mathrm{zz} / \mathrm{m}^{3}$. Uzyskany wynik jest iloczynem wartości wskaźnika $0,94 \mathrm{zł} / \mathrm{m}^{3}$ i objętości zbiornika. Za: R. Miłaszewski, Metody określania kosztów środowiskowych i zasobowych spowodowanych użytkowaniem wód, „Rocznik Ochrony Środowiska” 2009, t. XI, s. 351.

*** Efekt ten wystąpi na gruntach ornych znajdujących się w pobliżu zbiornika o powierzchni 80 ha, gdzie będzie stosowane deszczowanie. W wyniku poprawy warunków wodnych nastąpi wzrost plonów w przypadku ziemniaków i kukurydzy na ziarno o odpowiednio 42 i $51 \%$ (za: R. Kledzik, M. Kropkowski, C. Rzekanowski, J. Żarski, Ocena efektywności ekonomicznej nawadniania wybranych upraw polowych, „Infrastruktura i Ekologia Terenów Wiejskich” 2015, nr II/1, s. 298). Obliczono, iż w przypadku ziemniaków nastąpi wzrost plonu o 204,6 dt/ha przy cenie $64,45 \mathrm{dt} / \mathrm{ha}$, a w przypadku kukurydzy wzrost o $37,5 \mathrm{dt} /$ ha przy ceny $66,87 \mathrm{zł}$ za dt. Koszty nawadniania przyjęto na poziomie 2346,00 zł/ha dla ziemniaka i 2882,50 zł/ha dla kukurydzy (ibidem).

**** Korzyść ta odpowiada wartości strat, których uda się uniknąć dzięki budowie zbiornika (za: H. Arkadiusz, Ocena efektywności ekonomicznej eksploatacji zbiornika retencyjnego „,Stupsko”, „Studia Ekonomiczne” 2013, Uniwersytet Ekonomiczny w Katowicach, nr 136, s. 108). Z informacji zawartych w dokumencie pt. Raport $z$ wykonania map zagrożenia powodziowego i map ryzyka powo-

dziowego (KZGW 2015, s. 89) wykorzystano wartość potencjalnych strat dla gruntów ornych (1428 zł/ha) oraz terenów zielonych $(674 \mathrm{zł} / \mathrm{ha})$. Ustalono, iż bezpośrednio zagrożonych powodzią jest $2 \%$ powierzchni gruntów ornych i $0,4 \%$ powierzchni zlewni odpowiadającej powierzchni łąk. Uzyskany iloczyn skorygowano o wskaźnik prawdopodobieństwa wystąpienia powodzi Q 0,2\%.

***** Na podstawie Miejscowego planu zagospodarowania przestrzennego gminy Kleszczewo zidentyfikowano teren o powierzchni około 45 ha przeznaczony pod inwestycje (teren usług w zakresie sportu i rekreacji), który znajdzie się pod bezpośrednim oddziaływaniem zbiornika, co będzie skutkować wzrostem wartości gruntów. Nastąpi wzrost ceny $1 \mathrm{~m}^{2}$ gruntu o $15 \%$, tj. około $25 \mathrm{zł}$.

Źródło: opracowanie własne.

Uzyskane wskaźniki przedstawiają różnicę ogółu zdyskontowanych korzyści i kosztów finansowych oraz społecznych związanych z inwestycją. ENPV jest większa od zera, zatem należy uznać, iż projekt przyniesie istotne korzyści dla społeczności. Wartość wskaźnika EIRR przewyższa przyjętą stopę dyskontową, co również przekłada się na ekonomiczny zwrot. Podobnie jest w przypadku B/C - wartość korzyści ekonomicznych przekracza koszty inwestycji, czyli przedsięwzięcie jest społecznie pożądane.

\section{Podsumowanie}

Przeprowadzona analiza wykazała, że metody wykorzystywane do oceny efektywności ekonomicznej mogą z powodzeniem być stosowane w procesie ewaluacji 
ex ante rozwiązań środowiskowych, $\mathrm{w}$ tym $\mathrm{z}$ zakresu kształtowania retencji zlewni. Pewna niedoskonałość analizy kosztów i korzyści, jaką czasem jest brak metod obiektywnej kwantyfikacji i monetaryzacji owych kosztów i korzyści, powinna być pokonywana poprzez poszukiwanie nowych metod wyceny środowiska i efektów środowiskowych ${ }^{17}$. Przedstawiony zestaw korzyści nie wyczerpuje efektów, jakie potencjalnie może generować ten zbiornik. W dalszych analizach należałoby rozważyć uwzględnienie i wycenienie funkcji gospodarczej, sportowej i rekreacyjno-turystycznej, a także oszacowanie korzyści dostarczanych przez ekosystemy. Niewątpliwie zaprezentowane podejście ułatwia podejmowanie decyzji na etapie planowania.

\section{Liteatura}

Becla A., Czaja S., Zielińska A., Analiza kosztów - korzyści w wycenie środowiska przyrodniczego, Difin, Warszawa 2012.

Drobniak A., Zastosowanie analizy kosztów i korzyści w ocenie projektów publicznych, Wydawnictwo Akademii Ekonomicznej w Katowicach, Katowice 2002.

Evalsed. The Resource for the Evaluation of Socio-Economic Development, European Commission, Brussels 2013.

Ewaluacja. Poradnik dla pracowników administracji publicznej, Ministerstwo Rozwoju Regionalnego, Warszawa 2012.

Guide to Cost-benefit Analysis of Investment Projects. Economic Appraisal tool for Cohesion Policy 2014-2020, European Commission, Luxembourg 2014.

Halama A., Ocena efektywności ekonomicznej eksploatacji zbiornika retencyjnego „Stupsko”, „Studia Ekonomiczne” 2013, Uniwersytet Ekonomiczny w Katowicach, nr 136.

Kledzik R., Kropkowski M., Rzekanowski C., Żarski J., Ocena efektywności ekonomicznej nawadniania wybranych upraw polowych, „Infrastruktura i Ekologia Terenów Wiejskich" 2015, nr II/1.

Kryk B., Rachunek sozoekonomiczny działalności gospodarczej na przykładzie energetyki zawodowej regionu szczecińskiego, Wydawmictwo Naukowe Uniwersytetu Szczecińskiego, Szczecin 2003.

Malik K., Ewaluacja polityki rozwoju regionu. Metody, konteksty $i$ wymiary rozwoju zrównoważonego, „Studia KPZK PAN” 2011, z. 135.

MasterPlan dla obszaru dorzecza Odry, KZGW, Warszawa 2014.

Metodologiczny dokument roboczy. Projekt dokumentu roboczego dot. ewaluacji ex ante, Komisja Europejska, Bruksela 2005.

${ }^{17}$ D. Panusiak, Wartość środowiska w analizie kosztów i korzyści zbiorników wodnych w Polsce, „Ekonomia i Środowisko” 2010, nr 1 (37). 
Miłaszewski R., Metody określania kosztów środowiskowych i zasobowych spowodowanych użytkowaniem wód, „Rocznik Ochrony Środowiska” 2009, t. XI.

Mrozik K., Przybyła C., Problemy zarzadzania zasobami wodnymi w procesie suburbanizacji na przykładzie Poznańskiego Obszaru Metropolitalnego, „Finanse Komunalne” 2012, nr 12.

Olejniczak K., Mechanizmy wykorzystania ewaluacji. Studium ewaluacji średniookresowych Interreg III, Scholar, Warszawa 2008.

Panusiak D., Wartość środowiska w analizie kosztów i korzyści zbiorników wodnych w Polsce, „Ekonomia i Środowisko” 2010, nr 1 (37).

Piontek F., Metodyka oceny efektywności wydatkowania ekologicznych funduszy celowych, „Rocznik Ochrony Środowiska” 1999, t. I.

Przewodnik do analizy kosztów i korzyści projektów inwestycyjnych, Komisja Europejska, Bruksela 2008.

Raport z wykonania map zagrożenia powodziowego i map ryzyka powodziowego, KZGW 2015.

\title{
APPLICATION OF THE ECONOMIC EFFICIENCY FOR EX-ANTE EVALUATION OF SOLUTIONS SHAPING THE RETENTION CAPACITY OF THE RIVER CATCHMENT
}

\begin{abstract}
Asbtract
Cost-benefit analysis sets out one the one hand the potential benefits resulting from the implementation of specific activities and, on the other, the costs incurred on its implementation. The result is a clear information on the appropriateness of the solutions in terms of their effectiveness in delivering future results. In this sense, economic efficiency is used in the ex-ante evaluation, because in advance it indicates whether the planned activities are relevant from the social point of view. It takes into consideration specific socio-economic context and identifies potential problems and propose amendments, which have been shown in the case of the planned Tulce small retention reservoir.
\end{abstract}

Keywords: economic efficiency, ex-ante evaluation, cost-benefict analysis, Tulce small water retention reservoir

JEL Codes: O22, Q01, Q25, R58

Translated by Piotr Idczak

Praca zrealizowana w ramach projektu badawczego NCN nr2013/09/D/HS4/01858. 
